\title{
Diagnosis of toxoplasma infection in cardiac transplant recipients using the polymerase chain reaction
}

\author{
R Holliman, J Johnson, D Savva, N Cary, T Wreghitt
}

\begin{abstract}
Cardiac biopsy samples taken from transplant recipients around the time of primary toxoplasma infection were investigated by conventional histology and amplification of the P30 gene of Toxoplasma gondii by the polymerase chain reaction (PCR). Toxoplasma was detected more frequently by PCR than histology which may reflect the enhanced sensitivity of the former technique. Further studies are required to determine the optimal amount of tissue which should be examined by each technique and to develop a PCR assay capable of distinguishing between quiescent infection and active toxoplasmosis.
\end{abstract}

(f Clin Pathol 1992;45:931-932)

Toxoplasmosis can be life threatening to cardiac transplant recipients. Those at greatest risk are Toxoplasma specific antibody negative recipients who are exposed to the parasite for the first time when receiving viable cysts in the organ graft of seropositive donors. About $60 \%$ of such mismatches result in severe toxoplasma infection, although this incidence is reduced significantly when prophylaxis with pyrimethamine is given. ${ }^{1}$ Primary toxoplasma infection originating in the transplanted heart can be diagnosed by serological or histological methods. The infected recipient usually has detectable specific IgM and rising titres of IgG, but discordant findings have been reported. ${ }^{2}$ Histological examination may give false negative

Toxoplasma Reference Laboratory, St George's Hospital, London SW17 0QT R Holliman

J Johnson

Department of

Biochemistry and

Physiology, University

of Reading

D Savva

Department of

Histopathology,

Papworth Hospital,

Cambridge

N Cary

Clinical Microbiology

and Public Health

Laboratory,

Addenbrooke's Hospital, Cambridge T Wreghitt

Correspondence to:

Dr R E Holliman

Accepted for publication

6 April 1992 infection few cysts, even in severe, acute infection. The differentiation of toxoplasma infection and acute rejection can be problematic and the two conditions may be concomitant. We used the polymerase chain reaction (PCR) to investigate cardiac biopsy samples in cases of acute toxoplasmosis associated with heart transplantation and compared the findings with those obtained with conventional histological examination.

\section{Methods}

Toxoplasma DNA was amplified using the PCR and two sets of oligonucleotide primers based on the published sequence of the P30 gene. Amplification reactions were performed, as described previously, using serial cycles of PCR resulting in a 914 and then a 522 base pair fragment of DNA. Amplified fragments were visualised in ethidium bromide stained gels and by DNA-DNA hybridisation using ${ }^{32} p$ radiolabelled 522 base pair fragment as a specific probe. ${ }^{3}$ Primary toxoplasma infection was diagnosed by serological investigation of toxoplasma specific IgG and IgM. ${ }^{4}$ Cardiac biopsy samples were taken from heart transplant recipients around the time of infection and examined by PCR and conventional histological techniques.

\section{Results}

A total of 15 biopsy samples taken from seven cardiac transplant recipients with acute toxoplasmosis were investigated. A comparison of histological findings and detection of toxoplasma by PCR is presented in the table.

Comparison of histology and PCR results with serological findings for seven patients with primary donor acquired $T$ gondii

\begin{tabular}{|c|c|c|c|c|}
\hline Case No & Biopsy date & Histological findings & $P C R$ & $\begin{array}{l}\text { Timing of } T \text { gondii } \\
\text { seroconversion (transplantation date) }\end{array}$ \\
\hline 1 & $\begin{array}{l}02 / 05 / 84 \\
23 / 05 / 84\end{array}$ & $\begin{array}{l}\text { Negative } \\
\text { Toxo seen }\end{array}$ & $\overline{+}$ & $\begin{array}{l}22 \text { May } 1984 \\
(26 / 04 / 84)\end{array}$ \\
\hline 2 & $\begin{array}{l}27 / 04 / 82 \\
06 / 05 / 82 \\
17 / 05 / 82\end{array}$ & $\begin{array}{l}\text { Negative } \\
\text { Negative } \\
\text { Negative }\end{array}$ & $\begin{array}{l}+ \\
+ \\
+\end{array}$ & $\begin{array}{l}\text { End May } 1982 \\
(20 / 04 / 82)\end{array}$ \\
\hline 3 & $\begin{array}{l}29 / 07 / 85 \\
09 / 08 / 85 \\
05 / 09 / 85\end{array}$ & $\begin{array}{l}\text { Negative } \\
\text { Negative } \\
\text { Negative }\end{array}$ & $\begin{array}{l}+ \\
+ \\
+\end{array}$ & $\begin{array}{l}\text { 1985-88 Serum samples not available } \\
\text { between these dates. Infection } \\
\text { probably took place in } 1985 \\
(18 / 07 / 85)\end{array}$ \\
\hline 4 & $13 / 11 / 87$ & Negative & + & $\begin{array}{l}\text { March-November } 1987 \\
\text { Serum samples not available between } \\
\text { these dates } \\
(03 / 09 / 87)\end{array}$ \\
\hline 5 & $\begin{array}{l}17 / 11 / 87 \\
12 / 01 / 88\end{array}$ & $\begin{array}{l}\text { Negative } \\
\text { Negative }\end{array}$ & - & $\begin{array}{l}\text { December 1987-January } 1988 \\
(19 / 09 / 87)\end{array}$ \\
\hline 6 & $\begin{array}{l}21 / 09 / 81 \\
29 / 09 / 81\end{array}$ & $\begin{array}{l}\text { Negative } \\
\text { Toxo seen }\end{array}$ & $\dot{+}$ & $\begin{array}{l}\text { End October } 1991 \\
(10 / 09 / 81)\end{array}$ \\
\hline 7 & $\begin{array}{l}30 / 06 / 83 \\
26 / 07 / 83\end{array}$ & $\begin{array}{l}\text { Negative } \\
\text { Negative }\end{array}$ & - & $\begin{array}{l}\text { Mid July } 1983 \\
(22 / 06 / 83)\end{array}$ \\
\hline
\end{tabular}


Toxoplasma was detected in two of the seven cases by histology and in five cases using PCR.

\section{Conclusions}

Previous studies have shown that a single toxoplasma organism can be detected by PCR and that the method is highly specific. ${ }^{3}$ Contamination of the reactions leading to false positive results was unlikely as control samples of known toxoplasma free tissue repeatedly failed to produce amplification products. Consequently the enhanced detection of toxoplasma by PCR compared with histology may reflect the superior sensitivity of the former technique. In its present form the PCR assay will not distinguish quiescent cysts from active infection with free trophozoites of $T$ gondii. This problem may be overcome by the development of stage specific primers. As the distribution of toxoplasma in infected tissue is uneven, sampling error could result in discordant histological and PCR findings. The optimal amount of tissue which should be examined by each technique is not established.

Our results indicate that PCR can be used to detect $T$ gondii in cardiac biopsy samples taken from transplant recipients with primary, organ graft related toxoplasmosis. This method may be more sensitive compared with conventional histological examination. Further studies are in hand to define the application of PCR in organ transplantation for the diagnosis of primary infection and the identification of organ grafts which contain the parasite.

The development of the PCR assay for Toxoplasma was supported by the Medical Research Council. We are grateful to Mrs D Lyndon for the preparation of the typescript.

1 Speirs GE, Hakim M, Calne RY, Wreghitt TG. Relative risk of donor-transmitted Toxoplasma gondii infection in heart, liver and kidney transplant recipients. Clin Transplant 1988;2:257-60.

2 Holliman RE, Johnson J, Burke M, Adams S, Pepper JR. False negative dye-test findings in a case of fatal toxoplasmosis associated with cardiac transplantation. $\mathcal{F}$ Infect 1990;21:185-9.

3 Savva D, Morris JC, Johnson JD, Holliman RE. Polymerase chain reaction for detection of Toxoplasma gondii. $\mathfrak{7} M e d$ Microbiol 1990;32:25-31.

4 Wreghitt TG, Hakim M, Gray J, et al. Toxoplasmosis in heart and heart and lung transplant recipients. $\mathcal{f}$ Clin Pathol 1989;42:194-9.
Department of Pathology, Royal College of Surgeons in Ireland,

Dublin/Beaumont Hospital, Dublin, Ireland

A M Dorman

D Chin

$M$ Leader

Correspondence to:

Dr A M Dorman,

Department of

Histopathology, Royal Free

Hampstead NHS Trust,

Pond Street, London NW3

2QG.

Accepted for publication

6 April 1992

\begin{abstract}
Sections (5 $\mu \mathrm{m}$ thick) from 101 primary adenocarcinomas (including ovarian, colorectal, gastric, breast, oesophageal, prostatic, pancreatic, endometrial and gall bladder) were incubated with anticolon specific antigen (CSA) and anticolon ovarian tumour antigen (COTA) antibodies using the peroxidase antiperoxidase technique with positive and negative controls. Anti-CSA positivity was seen in 19 of 20 colonic adenocarcinomas, but it was also seen in a large number of the other tumours. While anti-COTA staining was positive in 16 of 20 colonic adenocarcinomas and 20 of 30 ovarian adenocarcinomas, it was also positive in a large number of the tumours.

Anti-CSA and anti-COTA are not adequately specific in the identification of a colonic or ovarian origin of an adenocarcinoma and cannot reliably be applied to the identification of a metastatic adenocarcinoma of unknown primary site.
\end{abstract}

(f Clin Pathol 1992;45:932-933)
A patient with metastatic adenocarcinoma of unknown primary site is a relatively common clinical problem. The identification of an antigen specific for a primary site, such as colon or ovary would have the benefit of minimising invasive and expensive investigations in untreatable patients and would also indicate the surgical and chemotherapeutic regimens in potentially curable patients.

Since the discovery of carcinoembryonic antigen (CEA) in colon cancer other more allegedly specific colon cancer associated antigens (colon specific antigen (CSA) and colon ovarian tumour antigen (COTA)) have been identified.

CSA is a heat stable, mucin associated antigen present in normal colonic epithelial cells and is expressed in greater quantities in colonic adenocarcinomas.

COTA is a heat stable antigen present in colonic adenomatous polyps and adenocarcinomas but not in normal colonic epithelium and it is also present in mucinous ovarian tumours. $^{1}$

In 1986 Pant et al described the sensitivity and specificity of goat anti-COTA antibody to 